\title{
ОДГОВОРНО ХРАНЕЊЕ
}

Душанка Матијевић, ${ }^{1}$ Светлана Младеновић Јанковић, ${ }^{2}$ Анђелка Котевић ${ }^{3}$

\section{RESPONSIVE FEEDING}

Dušanka Matijević, Svetlana Mladenović Janković, Anđelka Kotević

\section{Сажетак}

Одговорно храњенејеједна од одредница развоја деие током раног детинства. Подразумева адекватан одговор на потребе и сигнале детета током хранења и обострану размену осећања. Одговорно храњење пре свега истиче да није само значајно шта дете једе већ и како, када и у каквој атмосфери је дете храњено. На тај начин прочес храњена може бити извор радости, дељења лепих заједничких тренутака, али нажалост и извор страха, напетости и непријатности. Стилови родитељства у одгајању деце се одражавају и на храњење. Ауторитативни стил је онај који је препоручен и који се базира на позитивном подстицану детета, разумевању његових осећања и учењу како да их контролише и регулише. Родитељи успостављају јасна правила понамања, али, такође, дозвољавају деци да развију аутономију личности. Ови родитељи су склонији од других да примењују све аспекте храњења према потребама детета. Основни кораци у одговорном храњењу подразумевају постојење дневне рутине, препознавање сигнала које дете упућује мимиком или гласом, адекватан одговор на дететове сигнале уз подрику и разумевање и разумљивост и предвидљивост одговора родитеља за дете. $У$ ииљу унапређена родитељских вештина, применују се различите стратегије, а као најделотворније су се показале комбиноване свеобухватне програмске интервениије уз широку доступност превентивних кућних посета породицама са децом.

Кључне речи: одговорно храњење, рани развој, потребе, рутина, осећања.

\section{Summary}

Responsive feeding is a determinant of early child development. It means adequate response to the child needs and exchange of emotions during feeding process. Responsive feeding primarily emphasizes that it is not only important what a child eats but also how, when and in what kind of atmosphere the child is fed. In this way, the feeding process can be a source of joy, sharing beautiful moments, but unfortunately also a source of fear, tension and discomfort. Styles of parenting are also reflected in feeding. The authoritative style is one that is recommended and based on the positive stimulation of the child, understanding of his feelings and learning how to control and regulate them. Parents establish clear rules of behavior, but also allow children to develop personality autonomy. These parents are more inclined than others to apply all aspects of feeding to the needs of the child. The basic steps in responsive feeding involve the existence of a daily routine, recognizing the signal that a child produce by a tone or voice, an adequate response to the child's signals with support and understanding, and the comprehensibility and predictability of the parent's response to the child. In order to improve parental skills, different strategies are being applied, and the most effective are combined program interventions with the wide availability of preventive home visits to families with children.

Key words: responsive feeding, early child development, needs, routine, feelings.

\footnotetext{
${ }^{1}$ Проф. др Душанка Матијевић, Градски завод за јавно здравље Београд, Србија.

${ }^{2}$ Прим. мр сц. мед. Светлана Младеновић Јанковић, Градски завод за јавно здравље Београд, Србија.

${ }^{3}$ Анђелка Котевић, виша медицинска сестра, Градски завод за јавно здравље Београд, Србија.
} 
УВОД

$\mathrm{O}$ дговорно храњење подразумева посебан реципрочан однос размене осећања детета и родитеља приликом храњења, где дете, пре свега, испољава знаке глади или ситости за које се очекује да их родитељ препозна и адекватно на њих реагује. Уз обезбеђење адекватног оброка по обиму и саставу, родитељ развија окружење које подржава дете, уз развој здравих облика понашања у вези исхране, укључујући вештину саморегулације и контроле уношења хране..$^{(1)}$

Храњење је комплексан биопсихосоцијални процес кога чине научени обрасци понашања, социјална очекивања, усвојени укуси хране, као и ставови и осећања о храњењу уопште. Везано је непосредно и за процес глади у смислу преживљавања, апетита, жеље за самонаграђивањем храном која се воли, али и тенденцијом очувања здравља и обезбеђења адекватног раста и развоја. ${ }^{(2)}$

Неретко се заборавља да је суштина храњења заправо одржање живота. Међутим, храњење је далеко више од пуке “допуне аутомобила горивом” односно “пуњења детета храном".

Једење и храњење рефлектује наше ставове и односе са другима, као и нама самима. Храњење детета од стране родитеља је размена љубави са дететом, поверења, прихватања, развоја контроле. Стога оно може бити извор радости, дељења лепих заједничких тренутака, али нажалост и извор страха, напетости и непријатности. ${ }^{(3)}$

Одговорно храњење пре свега истиче да није само значајно шта дете једе, већ и како, када, где и од стране кога је дете храњено.

Човек је рођен са способношћу да сам регулише унос енергије у организам, па и беба "природно” зна када је гладна, односно сита, чак и колико треба да једе за правилан раст и развој.
Новорођенчад до трећег месеца испољавају своју потребу за храном тако што плачу.

Касније развијају неке друге знаке у смислу покрета руку ка устима или глави у случају глади или окрећући тело или главицу од нежељене хране, а могу и да испљуну храну, ако су сити. Стога је врло важно да родитељи препознају знаке глади и ситости код детета и да на то реагују на адекватан начин, промптно, доследно, прилагођено узрасту детета и увек уз емотивну подршку.

Треба имати на уму да се потребе и вештине храњења детета развијају паралено са његовим моторним, когнитивним и социјалним развојем у првим годинама живота. ${ }^{(4)}$

Низ аутора истиче да одговорно храњење има у значајној мери теоретску основу у одговорном родитељству. ${ }^{(5)}$

\section{ОДГОВОРНО ХРАЫЕНЕ}

Термин “одговорно храњење" је први пут уведен као саставни део развојне психологије и психо-социјалне заштите са циљем разјашњења могућих појава и ситуација везаних за храњење деце од стране родитеља, које се пре свега базирају на реципроцитету.

Деца имају природну способност да једу онолико колико им је потребно, што прати одговарајући раст и развој и да једу храну коју једу њихови родитељи. ${ }^{(6)}$

Одговорно храњење према E. Setter, уз реципроцитет, подразумева и прецизно утврђивање шта је чија одговорност (Слика 1): 
Слика 1. Прецизно утврђивање шта је чија одговорност (E. Setter).

\begin{tabular}{|l|} 
Новорођенчад \\
Родитељ: Шта ће дете да једе \\
Дете: $\quad$ Колико ће да једе \\
\end{tabular}

\section{Oдојчаd}

Родитељ: Шта, где и како ће дете да једе

Дете: Колико и да ли ће да једе

\author{
Мала и старија деца \\ Родитељ: Шта, где и како ће \\ дете да једе \\ Дете: Колико и да ли ће да једе
}

Родитељи имају свој “посао" око храњења деце, док је “посао” деце да једу.

Посао родитеља је да:

- бира и припрема храну за дете;

- обезбеђује редовне оброке и ужине;

- настоји да се дете осећа пријатно док једе;

- показује детету вештине које треба да савлада када је у питању храна као и понашање за време оброка;

- посматра стечена знања детета о храни без обзира на афинитет детета према истој;

- не дозвољава нарушавање динамике оброка и ужина између оброка, осим узимања воде;

- омогућава правилан раст и развој детета у складу са његовим потенцијалима и потребама.

Посао детета је да:

- једе онолико колико му је потребно;

- научи да једе храну коју једу и његови родитељи;

- расте и развија се у складу са предвиђањима и очекивањима;

- за време оброка се понаша онако како би требало.

\section{СТИЛОВИ РОДИТЕЉСТВА И ОДГОВОРНО ХРАЫЕЫЕ}

Родитељски стил подразумева психолошку основу за стратегије и праксу коју родитељи примењују у гајењу сопственог детета и која заправо одсликава целокупну емоционалну климу у кући, односно у породици. ${ }^{(7)}$ Стога је сасвим очекивано да се стилови родитељства рефлектују на начин како родитељи хране децу, односно на интерактивне обрасце понашања у том процесу.

Black и Hurley су утврдили четири родитељска стила у раном развоју деце, која се у потпуности могу применити и на одговорно храњење у смислу комбинације, прихватања и релевантног одговора родитеља на потребе детета, са захтевношћу и контролом. $^{(8)}$ То су: ауторитативни, ауторитарни, попустљив и занемарујући стил.

\section{Ауторитативно родитељство}

Овај стил врло често се препознаје као “баш онакав какав би требало да буде” јер подржава, пре свега, умереност и избалансираност и кад су у питању захтеви родитеља према детету и одговор на потребе детета од стране родитеља.

Стил се базира се на позитивном подстицању детета, разумевању његових осећања и учењу како да их контролише и регулише. Родитељи успостављају јасне стандарде за своју децу, прате утврђена ограничења, али, такође, дозвољавају деци да развију аутономију личности. Управо ови родитељи су склонији од других да примењују све аспекте одговорног храњења. Код њихове деце са друге стране уочава се бржи развој говора и бржи когнитивни развој у целини и ова деца раније почињу сама да се хране (Табела 1). ${ }^{(9)}$ 
Табела 1. Пример прогреса одговорног храњења код деие и родитеља.

\begin{tabular}{|c|c|c|c|c|c|}
\hline $\begin{array}{l}\text { P. } \\
\text { бр. }\end{array}$ & \begin{tabular}{|l|} 
Узраст у \\
месецима
\end{tabular} & $\begin{array}{l}\text { Припрема } \\
\text { родитеља }\end{array}$ & $\begin{array}{l}\text { Дечије вештине/ } \\
\text { сигнали }\end{array}$ & $\begin{array}{l}\text { Одговорност } \\
\text { родитеља }\end{array}$ & $\begin{array}{l}\text { Шта је дете } \\
\text { научило }\end{array}$ \\
\hline 0 & 1 & 2 & 3 & 4 & 5 \\
\hline 1 & до 6 & $\begin{array}{l}\text { Спремни да хране } \\
\text { дете када показује да } \\
\text { је гладно }\end{array}$ & $\begin{array}{l}\text { Сигнали } \\
\text { глади/ситости } \\
\text { гласом, мимиком, } \\
\text { покретима }\end{array}$ & $\begin{array}{l}\text { Одговор на } \\
\text { сигнале: храни } \\
\text { дете кад је гладно } \\
\text { стане кад је сито }\end{array}$ & $\begin{array}{l}\text { Родитељ ће } \\
\text { одговорити на } \\
\text { његове потребе }\end{array}$ \\
\hline 2 & $7-12$ & $\begin{array}{l}\text { Обезбеђује удобан } \\
\text { смештај детету уз } \\
\text { породичну рутину } \\
\text { приликом јела }\end{array}$ & $\begin{array}{l}\text { Седи, жваће и гута } \\
\text { получврсту храну, } \\
\text { само једе прстима }\end{array}$ & $\begin{array}{l}\text { Одговор на } \\
\text { сигнале: Уводи } \\
\text { различите } \\
\text { текстуре и укусе } \\
\text { приликом } \\
\text { храњења. } \\
\text { Подржава дете у } \\
\text { покушајима да } \\
\text { само једе } \\
\end{array}$ & $\begin{array}{l}\text { Почиње само да } \\
\text { се храни, проба } \\
\text { нове текстуре и } \\
\text { укусе и забавља } \\
\text { се кад једе }\end{array}$ \\
\hline 3 & $12-23$ & $\begin{array}{l}\text { Нуди 3-4 здрава } \\
\text { оброка и 2-3 ужине } \\
\text { сваки дан, даје храну } \\
\text { која се може прстима } \\
\text { узети из тањира, } \\
\text { жвакати и гутати }\end{array}$ & $\begin{array}{l}\text { Самостално једе } \\
\text { разну врсту хране, } \\
\text { користи безбедно } \\
\text { посуђе за малу децу } \\
\text { захтеве изражава } \\
\text { речима }\end{array}$ & $\begin{array}{l}\text { Одговара на } \\
\text { сигнале глади } \boldsymbol{u} \\
\text { ситости: } \\
\text { подржава напоре } \\
\text { детета да се само } \\
\text { храни }\end{array}$ & $\begin{array}{l}\text { Проба нову } \\
\text { храну, нешто } \\
\text { ради само, за } \\
\text { друго тражи } \\
\text { помоћ, има } \\
\text { поверења да ће } \\
\text { родитељ } \\
\text { одговорити } \\
\text { његовим } \\
\text { захтевима }\end{array}$ \\
\hline
\end{tabular}

Сви остали стилови родитељства (ауторитарни, попустљив и занемарујући) пра-

ћени су различитим облицима и примерима неодговорног храњења (Табела 2).

Табела 2. Стилови родитељства и храњења и њихове последице.

\begin{tabular}{|c|c|c|c|c|c|}
\hline $\begin{array}{l}\text { P. } \\
\text { бp. }\end{array}$ & $\begin{array}{l}\text { Стилови } \\
\text { родитељства }\end{array}$ & $\begin{array}{l}\text { Стилови } \\
\text { храњења }\end{array}$ & Особине родитеља & Особине деце & Последице \\
\hline 0 & 1 & 2 & 3 & 4 & 5 \\
\hline 1 & \begin{tabular}{|l|} 
Ауторитативно \\
(демократско) \\
- укључено \\
- негујуће \\
- у складу са \\
потребама детета \\
- ограничења
\end{tabular} & $\begin{array}{l}\text { Одговорно } \\
\text { храњење } \\
\text { (захтеви и } \\
\text { одговорност) }\end{array}$ & $\begin{array}{l}\text { Све што се подразумева } \\
\text { под одговорним } \\
\text { храњењем }\end{array}$ & \begin{tabular}{|l|} 
Позитивно \\
понашање: \\
прихвата \\
понуђену храну \\
схвата да \\
родитељ \\
уважава његове \\
сигнале \\
глади/ситости \\
\end{tabular} & $\begin{array}{l}\text { - дете је научило да } \\
\text { једе кад је гладно и да } \\
\text { престане кад је сито } \\
\text { - само се храни } \\
\text { - време оброка је } \\
\text { забавно } \\
\text { - развија здраве навике } \\
\text { исхране }\end{array}$ \\
\hline 2 & \begin{tabular}{|l} 
Aуторитарно \\
(контролишуће) \\
- рестриктивно \\
- форсирано \\
- низак ниво неге \\
- не узима у обзир \\
потребе детета \\
строга \\
ограничења
\end{tabular} & $\begin{array}{l}\text { Неодговорно } \\
\text { храњење } \\
\text { (захтеви, } \\
\text { форсирање и } \\
\text { строга } \\
\text { контрола) }\end{array}$ & $\begin{array}{l}\text { - доминатна улога } \\
\text { родитеља - нема } \\
\text { реципроцитета } \\
\text { - форсирано храњење и } \\
\text { строга контрола } \\
\text { • храњење на силу } \\
\text { - викање на дете ако } \\
\text { одбија храну }\end{array}$ & \begin{tabular}{|l|} 
Негативно \\
понашағе: \\
не говори \\
ништа \\
одбија храну, \\
плаче, \\
деструктивно је \\
или заједљиво
\end{tabular} & $\begin{array}{l}\text { - стрес, напетост или } \\
\text { избегавање оброка } \\
\text { - нема саморегулације } \\
\text { храњења у складу са } \\
\text { глади/ситошћу } \\
\text { - једе и кад није гладно } \\
\text { - може да тражи и } \\
\text { забрањену храну } \\
\text { - могући мањак или } \\
\text { вишак телесне масе }\end{array}$ \\
\hline
\end{tabular}




\begin{tabular}{|c|c|c|c|c|c|}
\hline 3 & \begin{tabular}{|l|} 
Занемарујуће \\
(незаинтересо- \\
ваност) \\
- неангажовано \\
- без ограничења \\
- стихијски \\
- низак ниво нег
\end{tabular} & $\begin{array}{l}\text { Неодговорно } \\
\text { храњење (без } \\
\text { захтева и } \\
\text { одговорности) }\end{array}$ & $\begin{array}{l}\text { • нема помагања при } \\
\text { храњењу } \\
\text { • нема разговора у току } \\
\text { оброка } \\
\text { • без контроле врсте и } \\
\text { обима оброка } \\
\text { - без реципроцитета, } \\
\text { игнорисање сигнала } \\
\text { глади и ситости детета } \\
\text { - негативно окружење за } \\
\text { време оброка без } \\
\text { рутина, непоштовање } \\
\text { нутритивних потреба } \\
\text { детета, не зна се ни кад } \\
\text { шта и где дете једе } \\
\end{array}$ & $\begin{array}{l}\text { - доноси одлуку } \\
\text { када и шта ће да } \\
\text { једе и у којој } \\
\text { количини }\end{array}$ & $\begin{array}{l}\text { - не препознаје сигнале } \\
\text { глади и ситости } \\
\text { • једе кад му се понуди } \\
\text { храна јер је доступна } \\
\text { - могући мањак или } \\
\text { вишак телесне масе }\end{array}$ \\
\hline 4 & \begin{tabular}{|l|} 
Попустьиво \\
(све допуштено) \\
- без ограничења \\
- без укључивања \\
- негујуће
\end{tabular} & $\begin{array}{l}\text { Неодговорно } \\
\text { храњење (нема } \\
\text { захтева, све је } \\
\text { допуштено) }\end{array}$ & $\begin{array}{l}\text { - нема правила шта дете } \\
\text { једе } \\
\text { • храна као награда } \\
\text { • храна се користи за } \\
\text { контролу дететовог } \\
\text { понашања }\end{array}$ & \begin{tabular}{|l|} 
\\
доноси одлуку \\
када и шта ће да \\
једе и у којој \\
количини \\
\end{tabular} & $\begin{array}{l}\text { - унос хране са много } \\
\text { соли и шећера } \\
\text { једе мало воћа и } \\
\text { поврћа } \\
\text { - могући мањьк или } \\
\text { вишак телесне масе }\end{array}$ \\
\hline
\end{tabular}

На одговорно храњење могу утицати и други фактори као што су: социо-економски статус, окружење и социо-културални фактори, етничка припадност, традиција и обичаји. Рестриктван начини понашања родитеља у исхрани детета могу бити и покушаји родитеља да се изборе са прекомерном тежином, како детета, тако и сопственом. ${ }^{(10)}$

\section{ОСНОВЕ ОДГОВОРНОГ ХРАНЕНА}

Светска здравствена организација и УНИЦЕФ се залажу да одговорно храњење буде саставна компонента водича за адекватну исхрану, новорођене деце, одојчади и мале деце. ${ }^{(11,12)}$

Тако према СЗО и УНИЦЕФ-у прва препорука у одговорном храњењу деце је ексклузивно дојење до шест месеци, уз лагано увођење комплементарне исхране, с тим да дојење уз мешовиту исхрану може да се настави до краја друге године живота.

У почетку се пропоручују мале количине комплементарне исхране које се постепено повећавају, с тим да се беспрекорни хигијенски услови за припрему и чување комплементарне хране подразумевају.
Тако се препоручује следеће количине у односу на узраст:

- 200 ккал са 6-8 месеци;

- 300 ккал са 9-11 месеци;

• 550 ккал са 12-23 месеца.

Са узрастом детета постепено се повећава густина хране:

- 6 месеци - користи се измиксана и получврста храна;

- 7-8 месеци - могу сами да једу чврсту храну прстима. У овом узрасту треба избегавати храну која може довести до гушења детета као што су лешници, ораси, сирова шаргарепа и сл.;

- 12 месеци - једу исто што и остали чланови породице.

За здраво дете препоручује се следећа фреквенца комплементарних оброка:

- 6-8 месеци - 2-3пута дневно;

- 9 - 11 месци - 3-4 пута дневно;

- 12-23 месеца - као и у претходном случају са додатним ужинама (1-2) у току дана и то да буде нека воћка, комад хлеба, кекс...

Храњење детета никако није лак задатак и стога је успешна комуникација родитеља 
и детета врло важна. На тај начин ће се избећи: форсирано храњење против воље детета, претерано попуштање или незаинтересованост родитеља.

Зато су основни принципи одговорног родитељства кључни када је у питању и одговорно храњењење. ${ }^{(13)}$ То пре свега подразумева успостављање четири основна корака:

1. очекивана рутина, где дете зна шта га очекује за време оброка;

2. препознавање сигнала које дете упућује мимиком или гласом;

3. брз одговор на дететове сигнале уз подршку и разумевање;

4. разумљивост и предвидљивост одговора родитеља за дете.

\section{Препоруке за промовисање одговорног храњења}

Препоруке за одговорно храњење апострофирају значај активног ангажовања родитеља посебно када је у питању проблем одбијања хране од стране детета, као и значај развоја позитивног окружења за време оброка. ${ }^{(11,14)}$

Активно ангажовање родитеља:

- разговор и контакт погледом са дететом за време храњења;

- испуњавање очекивања детета;

- адекватан одговор на сигнале глади и ситости;

- директно храњење детета или помоћ старијем детету да само једе;

- обезбеђење здравих избора кад је у питању храна;

- обезбеђење здравог и укусног оброка за правилан раст и развој детета.

Превазилажење проблема одбијања хране:

- комбиновати различите врсте намирница, различите текстуре и укусе;

- применити методе подршке и охрабрења детета да поједе оброк;
- пратити напредак у храњењу полако уз мотивисање детета да једе;

- никад не хранити дете на силу, уколико одбија храну у одређеном моменту, сачекати и понудити касније.

Развој позитивног окружења:

- обезбедити пријатно и удобно окружење на месту где дете једе;

- дете треба да седи релаксирано, комфорно да се осећа пријатно;

- важно је да дете седи лицем у лице са другим члановима породице;

- уложити напор да оброци буду у исто време, на истом месту у познатим и предвидљивим околностима.

\section{Одговорно храњење у посебним окол- ностима}

Све препоруке за промовисање одговорног храњења треба схватити у контексту постојеће ситуације, с обзиром на то да некад постоје околности кад је важно бити флексибилан, одступити од општих правила и прилагодити се потребама детета у одређеном актуелном тренутку.

Исхрана болесног детета:

- хранити дете полако и стрпљиво;

- дати уситњену храну поготово ако дете има проблем са гутањем;

- дати детету омиљену храну;

- дати мале, али чешће оброке;

- ако се дете доји, чинити то чешће, продужити подој, повећати унос течности.

У току опоравка од болести одговорити адекватно на већу потребу за храном додатним оброцима и ужинама бар у наредне две недеље док траје опоравак.

Смањен апетит детета:

- хранити дете полако и стрпљиво;

- дати му омиљену храну;

- обезбедити чешће оброке;

- правити мање и чешће порције уместо три главна оброка. 
Дете одбија да једе:

- дати детету алтернтивну храну;

- дати храну која изгледа лепо и привлачно по боји и облику;

- разговарати са дететом, певати му;

- сачекати, па понудити поново;

- дете никако не би требало да једе само.

Постоје докази у истраживањима да је разговор са дететом за време оброка у директној корелацији са његовим раним paзвојем. ${ }^{(15)}$

Препоруке С3О за одговорно храњење

Одговорно храњење се препознаје као једна од кључних стратегија за постизање очекиваног раста и развоја детета у складу са његовим потенцијалима. Стога је СЗО дала врло експлицитне препоруке у вези са истим. ${ }^{(11)}$

Предуслов успешности одговорног храњења су рутине ${ }^{(15,16,17)}$ и то посебно везане за цео процес храњења у породици. Та рутина подразумева:

- исто место;

- исто време;

- удобност и пријатно окружење;

- адекватан модел понашања свих чланова породице за време оброка.

Уколико се у породици даје предност храни богатој воћем и поврћем, велика је вероватноћа да ће то дете прихватити и убудуће. И обрнуто, уколико породица предност даје намирницама где превладавају рафинисани угљени хидрати и засићене масти, врло је извесно да ће овакав начин исхране прихватити дете и у будућности. ${ }^{(18)}$

Препоруке СзО:

- непосредно храњење детета уз помоћ старије децие која се сама храни;

- препознавање сигнала глади и ситости од стране родитеља;

- лагано и стрпљиво храњење; ако дете одбије храну, сачекати и понудити поново;
- подршка детету да једе, без терања да једе на силу;

- ако деца одбијају да једу одређене врсте хране, пробати различите комбинације намирница, укуса, густине односно тврдоће хране (банана изгњечена или фрапе);

- применити разне методе подршке детету приликом храњења (игра, моделовање, прича, смех, певање);

- минимално ометање током храњења (ТВ), нарочито ако дете брзо губи интерес за храну;

- време храњења је и период учења и љубави (разговор, игра, директан контакт очима родитеља и детета....).

Показатељи одговорног храњењења

Било је много интервентних студија које су покушале да унапреде праксу пре свега мајки кад је у питању одговорно храњење деце. С обзиром на то да не постоје неки универзални индикатори евентуалног напретка у тој области, није увек било лако проценити успешност ових интервенција. $(19,20)$

Стогаје ICYN пројекат USAID-a (пројекат о исхрани одојчади и мале деце) ангажовао Истраживачки институт за исхрану у Перу да надзире примену препоручене праксе у вези одговорног храњења код 155 парова мајки и деце. Време трајања свакодневне обсервације понашања мајки и деце приликом храњења било је 12 часова, од 6 пута пре подне до 19 пута после подне.

Посматрана понашања приликом храњења:

- активности мајке да би подстакла дете да једе;

- разговор мајке са дететом за време оброка (нежно, стрпљиво);

- одбијање хране од стране детета;

- позиција детета за време главног оброка (држи га мајка, седи, стоји, шета);

- постојање било ког облика самосталног храњења; 
- коришћење безбедног посуђа за децу приликом храњења;

- околности храњења (позиција мајке, место где стоји јело, расположење мајке и детета, количина евентуално непоједене хране);

- да ли дете додирује посуђе са храном.

Резултати студије су указали на неколико индикатора који би најбоље могли да се користе за процену успешности одговорног храњења. Исти се односе на место где се одвија храњење (позиција мајке и детета, коришћење безбедног посуђа, присуство других чланова породице за време оброка и ометајућих фактора, као нпр. ТВ) и на специфичне интеревенције (игра мајке са дететом да би подстакла храњење и разговор са дететом за време оброка...). Теже је било мерити негативе реакције мајке, најчешће ако дете одбија храну (прекор или вика) иако таквих реакција није било више од $10 \%$.

Ова и друге интервентне студије указале су на сет индикатора који могу врло успешно да мере достигнућа или напредак када је у питање одговорно храњење (Табела 3 ).

Табела 3. Индикатори одговорног храњења.

\section{Индикатори одговорног храњења:}

- игра/смех;

- модел храњења (како једе друга особа, меда, куца...);

- привлачење пажње детета (нпр. играчком);

- разговор;

- место детета (у наручју мајке, на коленима, на кревету, на високој столици, на софи, фотељи и сл.);

- позиција детета (држи га мајка, седи, стоји, шета, седи);

- положај мајке (близак, лицем у лице, мајка са стране или позади детета);

- учесталост самосталног храњења (све време, већину времена, понекад, никад);

- учесталост додиривања безбедног посуђа (све време, већину времена, понекад, никад).

\section{ПРОГРАМСКИ ПРИСТУП}

Одговорно храњење препознаје се као једна од кључних стратегија раног раста и развоја и достизања максималних потенцијала детета и врло брзо је у последњим декадама укључено у здравствене политике не само високоразвијених земаља већ и земаља у развоју.

Стога УНИЦЕФ, СЗО, ПАХО и друге релевантне организације истичу значај и залажу се за укључивање одговорног храњења у све здравствене политике и релевантне програме. ${ }^{(21,22,23,24)}$

Посебно је препознат значај програма кућних посета с обзиром на могућност обуке чланова породице у кући, као и праћења и провере примене наученог у пракси.
Од посебног је значаја могућност промоције позитивног окружења у породици и достизања оних којима је ова врста помоћи најпотребнија, сиромашних, маргинализованих породица и сл.

Најбоље ефекте у поменутом смислу показале су комбиноване свеобухватне програмске интервенције: посете лекару и кућне посете (у нашим условима педијатар и посете поливалентне патронажне службе). $(25,26)$

Одговорно храњење је основа раног развоја детета јер није само важно шта дете једе већ и како, када, где и ко храни дете. Стога најновије издање "Животних порука" УНИЦЕФ-а препоручује одговорно храњење не само када је у питању комплементарна исхрана већ и дојење. ${ }^{(27)}$ 
Добробити одговорног храњења документоване су у читавом низу студија и интервенција и то у смислу утицаја на:

- укупан психо-социјални развој детета;

- моторички развој и физички раст;

- ментални развој;

- развој говора;

- развој опште (IQ) и емоционалне интелигенције (EQ);

- укупно здравље детета;

- здравље породице у целини.

\section{ЗАКљУЧЩИ}

1. Одговорно храњење подразумева посебан реципрочан однос размене осећања детета и родитеља приликом храњења где дете, пре свега, испољава знаке глади или ситости за које се очекује да их родитељ препозна и адекватно на њих реагује.

2. Уз обезбеђење адекватног оброка по обиму и саставу, родитељ развија окружење које подржава дете, уз здраве облике понашња у вези исхране, укључујући вештине саморегулације и контроле уношења хране. Храњење детета од стране родитеља је и размена љубави са дететом. Стога је врло важно да родитељи препознају знаке глади и ситости код детета и да на то реагују на адекватан начин, промптно, доследно, прилагођено узрасту детета и увек уз емотивну подршку.

3. Родитељски стилови подразумевају психолошку основу за стратегије и праксу коју родитељи примењују у гајењу сопственог детета, па се исти рефлектују на начин како родитељи хране децу односно на интерактивне обрасце понашања у том процесу.

4. Ауторитативни стил родитељства се препознаје као "баш онакав какав би требало да буде" и управо ови родитељи су склонији од других да примењују све аспекте одговорног храњења. Код њихове деце уочава се бржи развој говора и бржи ко- гнитивни развој у целини и ова деца раније почињу сама да се хране.

5. Сви остали стилови родитељства (ауторитарни, попустљив и занемарујући) праћени су различитим облицима и примерима неодговорног храњења.

6. Одговорно храњење уз реципроцитет, подразумева и прецизно утврђивање шта је чија одговорност: Родитељи имају свој “посао" око храњења деце, док је "посао" деце да једу. Активно ангажовање родитеља у храњењу детета посебно је важно као и развој позитивног окружења за време оброка.

7. Промовисање одговорног храњења некад се врши у посебним околностима када је важно бити флексибилан, одступити од општих правила и прилагодити се потребама детета у одређеном актуелном тренутку. То се посебно односи на дете које је болесно, које одбија храну или има слаб апетит. Никада не треба силом терати дете да једе. Ако одбија храну, сачекати па понудити поново.

8. Већи број интервентних студија покушао је да унапреди праксу пре свега мајки кад је у питању одговорно храњење деце као и да укаже на сет индикатора који могу врло успешно да мере достигнућа или напредак када је у питању одговорно храњење. Исти се односе на место где се одвија храњење као и на специфичне интеревенције у току храњења.

9. Одговорно храњење препознаје се као једна од кључних стратегија раног раста и развоја и достизања максималних потенцијала детета. Стога УНИЦЕФ, СЗО, ПАХО и друге релевантне организације истичу значај и залажу се у укључивање одговорног храњења у све здравствене политике и релевантне програме не само када је у питању комплементарна исхрана већ и дојење.

10. Одговорно храњење је основа раног развоја детета јер није само важно шта дете једе већ и како, када, где и ко храни дете. 
11. Добробити одговорног храњења су огромне и врло широке. Оно утиче на: психо-социјални развој детета, моторички и ментални развој, физички раст, развој говора, развој опште (IQ) и емоционалне интелигенције (EQ), као и на здравље детета и породице у целини.

\section{ЛИТЕРАТУРА}

1. Harbron J, Booley S, Najaar B.

Responsive Feeding: Establishing healthy eating behaviour early in life. S Afr Clin Nutr 2013; 26(3) (Suppl): S 141-149.

2. Satter E. Eating Competence - Definition and Evidence for the Stter Eating Competence Model. J Nutr Educ Behav. 2007; 39: S 142, S 153.

3. Satter E. The secret in a nutshell. In: Secrets of Feeding a Healthy Family, Madison, WIS: Kelcy Press; 2008, pg 2-14.

4. Lui Hy, Stein MT: Feeding behavior of infants and young children and its imapct on child psychosocial devlopment. Montreal: Centre of Excellence for Early Childhood Developmentand Strategic Knowledge Cluster on Early Child Development: 2012 / homepageon the internet/

http// www.child-ancyclopedia.com/ documents/ramsayANGxp.pdf

5. Black MM, Aboud FE. Responsive feeding is Embedded in a Theoretical Framework of resposive Parenting. J Nutr 2011; 141(3): 490-494.

6. Setter E. How to rise a good eaters. In: Ellen Setter's division of responsibility in feeding, 2013. http/ellynsetterinstitute.org.

7. Tamis-LeMonda Cs, Bornstein MH. Maternal responsiviness and early language acquisition. In: Kail R, Reese HW, editors, Advances in child development and behavior, San Diego, Academic Press, 2001.

8. Black MM, Hurley K. Infant Nutrition in Bremmer JG, Wachs Teitors. Handbook on infant development. New York:WileyBlackwell, 2010; 33-61.

9. Malmberg LE, Stein A, West A et al. Parent infant interaction: a growth model approach. Infant behav. Dev. 2007: 30(4): 615-630.

10. Hurley KM, Cross MB, Hughes SO. A systematic review of responsive feeding and child obesity in high income countries. J Nutr 2011: 141(3); 495-501.

11. WHO. Guiding principles for cemplementary feeding of the breastfed child, Geneva, WHO, 2003.

12. UNICEF. Child and mother nutrition survey in Bangladesh, 2005, Dhaka, Plan international 2005 /homepage on the internet/ 2012, Available from:

http:www.unicef/org/bnagladesh/Child and Mother Nutriton Survey.pdf.

13. Kral TV, Rauh EM. Eating behaviors of children in the context of their family environment. Physiol. Behav. 2010; 100: 567-73. /PMC free article/ PubMed.

14. Bradley RH: The home environment. Hnadbook of cultural developmental science, New York Psychologu Press 2010; 505-530.

15. Rajeshwari K. Unfant and Young child feeding guidelines. Infant and Young Child Fedding Chapter. Indian Academy of Pediatrics, 2010. Indian Pediatr. 2010; 47(12): 995-1004.

16. Knneth R. Ginsburg. The Importance of Play in Promoting Healthy Child development and Maintaining Strong parent - Child Bonds, http//:www.wess.wa.edu. $\mathrm{au} / \mathrm{pdf} /$ importanceofthe play_AAP.pdf) American Academy of Pediatrics, avialable, July 22. 2014.

17. Anderson SE, Whitaker RC. Husehold routines and obesity in US preschool aged children. Pediatrics, 2010; 125(39: 420-428. 18. Bauttele KN, Birnbaum AS et al. Assosiations between perceived family 
meal environment and parent intake of fruit, vegetables, and fat. J Nutr Educ Behav.

2003; 35(1): 24-29.

19. USAID'S Infant \& Young Children Nutrition Project. Measuring the quality of mother - child feeding interactions: A study of indicators for responsive feeding. 2015, www.IYCN.org orinfo@iycn.org

20. Kanshiro HC, Bartolini R. Research Project: responsive feeding in Peru:

Aplication and monitoring of interventions among families with small children from an area of the Ucayali region. Instituto de Ivestigacion Nutricional, Final report, 2009; 1-29.

21. WHO, UNICEF. Infant young child feeding counselling: an itegrated course. Geneva, WHO, 2000.
22. WHO, UNICEF. Global strategy for infant and young child feeding. Geneva, WHO, 2003.

23. Pan American Health Organization, WHO. Guiding principles for complementary feeding of the breastfeed child. Washington, DC:PAHO/WHO, 2003.

24. UNICEF. Care for feeding counselling card, 2009.

25. WHO. Nutrition, Complementary feeding, 2014, dostupno na:

http//:www.WHO.int/nutrition/topics/ complementary_feeding/en/

26. Engle PL, Pelto GH. Responsive feeding: Implications for Policy and Program Implementation. J Nutr 2011: vol.141(3): 508 -511.

27. UNICEF. Facts for life. New York, UNICEF, 2009.

Контакт: Проф. др Душанка Матијевић, Градски завод за јавно здравље Београд, Булевар деспота Стефана 54a, 11000 Београд, телефон: 0112078638 , e-mail:dusica.matijevic@zdravlje.org.rs 